\title{
From olive to olive oil: a general approach
}

\author{
Da oliveira ao azeite de oliva: uma abordagem geral \\ De oliveira al aceite de oliva: un enfoque general
}

Received: 02/28/2021 | Reviewed: 03/08/2021 | Accept: 03/09/2021 | Published: 03/17/2021

\author{
Bruna Sanches Silva \\ ORCID: https://orcid.org/0000-0003-0044-2282 \\ Universidade Federal dos Vales do Jequitinhonha e Mucuri, Brazil \\ E-mail: brs.sanches@hotmail.com \\ Marcio Schmiele \\ ORCID: https://orcid.org/0000-0001-8830-1710 \\ Universidade Federal dos Vales do Jequitinhonha e Mucuri, Brazil \\ E-mail: marcio.sc@ict.ufvjm.edu.br
}

\begin{abstract}
This study aimed to carry out a systematic literature review about olives, extraction methods, physical and chemical characterization and identity and quality parameters of olive oils, as well as technological alternatives for using byproducts. Olive oil is the oil extracted from the ripe fruits of the olive tree (Olea europaea L.). Trees have been cultivated in the Mediterranean Region for several centuries and thousands of cultivars differ by weight, size and chemical characteristics of the fruits. Currently, olive oil is produced worldwide and the olive plant was recently introduced in the city of Diamantina, Minas Gerais. The lipid content is mostly composed of oleic acid and smaller fractions of phenolic compounds, phytosterols and pigments, substances with antioxidant and bioactive activities that promote oxidative stability of the oil and beneficial effects on human health. The main extraction of olive oil consists of crushing, pressing and centrifuging, generating by-products that can be reused for recovery of compounds or generation of new products in the food industry. After extraction, the oil is submitted to several physical and chemical analyzes to define the identity and quality parameters, according to international standards. The main characteristics that define the quality of olive oil are free acidity, peroxide index, specific extinction index, instrumental color and fatty acids profile.
\end{abstract}

Keywords: Lipids; Fatty acids; Lipid oxidation; Olive pomace; Added value.

\section{Resumo}

O objetivo deste estudo foi o de realizar uma abordagem sistemática de literatura sobre as olivas, extração, caracterização e parâmetros de identidade e de qualidade dos azeites, bem como as alternativas tecnológicas de aproveitamento dos resíduos. O azeite de oliva é o óleo comestível extraído dos frutos maduros da oliveira (Olea europaea L.). As árvores são cultivadas na Região Mediterrânea há vários séculos e existem milhares de cultivares que se diferem pelo peso, tamanho e características químicas dos frutos. Atualmente, o azeite de oliva é produzido em todo o mundo e o plantio de olivas foi recentemente introduzido na cidade de Diamantina, Minas Gerais. O extrato etéreo é composto, em maior parte, por ácido oleico e por menores frações de compostos fenólicos, fitoesteróis e pigmentos, substâncias antioxidantes e bioativas que promovem a estabilidade oxidativa do óleo e possuem efeitos benéficos à saúde humana. O principal método de extração do azeite de oliva é composto basicamente por trituração, prensagem e centrifugação, gerando resíduos que podem ser reaproveitados para recuperação de compostos ou geração de novos produtos na indústria alimentícia. Após extraído, o azeite é submetido a diversas análises físicas e químicas para definição do padrão de identidade e qualidade, de acordo com as normas internacionais. As principais características que definem a qualidade do azeite de oliva são a acidez titulável total, índice de peróxidos, extinção específica no ultravioleta, cor instrumental e perfil de ácidos graxos.

Palavras-chave: Lipídeos; Ácidos graxos; Oxidação lipídica; Bagaço; Valor agregado.

\section{Resumen}

El objetivo de este estudio fue realizar una revisión sistemática de la literatura sobre aceituna, métodos de extracción, caracterización física y química y parámetros de identidad y calidad de los aceites de oliva, así como alternativas tecnológicas para el uso de los subproductos. El aceite de oliva es el aceite comestible extraído de los frutos maduros del olivo (Olea europaea L.). Los árboles se cultivan en la Región del Mediterráneo desde hace varios siglos y existen miles de cultivares que difieren en peso, tamaño y características químicas de los frutos. Actualmente, el aceite de oliva se produce en todo el mundo y la plantación de aceitunas se introdujo recientemente en la ciudad de Diamantina, Minas Gerais. El extracto etéreo es compuesto principalmente por ácido oleico y fracciones menores de compuestos fenólicos, fitoesteroles y pigmentos, sustâncias con actividades antioxidantes y bioactivas que promueven la estabilidad oxidativa del aceite y tienen efectos beneficiosos para la salud humana. La principal extracción del aceite 
de oliva consiste en triturar, prensar y centrifugar, generando subproductos que pueden reutilizar para la recuperación de compuestos o generar nuevos productos en la industria alimentaria. Después de la extracción, el aceite se somete a varios análisis físicos y químicos para definir la identidad y calidad, según estándares internacionales. Las principales características que definen la calidad del aceite de oliva son la acidez total titulable, el índice de peróxidos, el índice de extinción específica en el ultravioleta, el color instrumental y el perfil de ácidos grasos.

Palabras clave: Lípides; Ácidos grasos; Oxidación de lípidos; Orujo de aceituna; Valor agregado.

\section{Introduction}

Olive oil is the oil extracted from the olive tree fruits (Olea europaea L.), trees grown in the Mediterranean Region for several centuries and the different existing cultivars differ by weight, size and chemical characteristics of the fruits. Currently, olive oil is produced worldwide and olive growing was recently introduced in the city of Diamantina, Minas Gerais.

\section{Methodology}

This research carried out a systematic literature review, and the scientific databases used in the articles search were: ScienceDirect (https://www.sciencedirect.com), Scopus (http://www.scopus.com), PubMed $\quad$ (MEDLINE) (http://www.ncbi.nlm.nih.gov/pubmed), CAPES / MEC Journal Portal (http://www.periodicos.capes.gov.br), Scielo Scientific Electronic Library Online (https://www.scielo.org/) and Science.gov (https://www.science.gov/). The inclusion criteria took into account complete and timeless articles, books and book chapters that presented specific content on the topic addressed. The search was guided by the use of the terms: olives, chemical composition, oil extraction, identity and quality parameters, characterization of olives and oils, olives by-products for technological purposes.

\section{Literature Review}

\subsection{Olive tree}

The olive trees (Olea europaea L.) are probably originated from the Asian region and have spread to the Mediterranean region, where they showed excellent adaptation. That species is known for being self-sterile, that is, fruiting occurs through cross-pollination. For this reason, thousands of cultivars (a group of plants with similar phenotypic and genotypic characteristics) originated with different sizes, shapes, unique chemical and sensory characteristics. Besides, it is more difficult to reproduce them by traditional genetic methods. For these reasons, the combination of these characteristics is highly sought after by beginning markets in the cultivation of olive trees (Ilarioni \& Proietti, 2014; Rodrigues, Casal, Peres, Baptista \& Pereira, 2020).

The olives morphological classification is widely used in research to describe fruits and distinguish cultivars. According to the International Olive Council Standards (IOC), the weight of the olives can be determined as low $(<2 \mathrm{~g})$, medium (2-4 g), high (4-6 g) and very high (>6 g), and the shape of the fruit (aspect ratio) as the ratio of width by a length equal to spherical (<1.25), ovoid (1.25-1.45) and elongated (> 1.45) (Ebiad \& Abu-Qaoud, 2014).

The fruits are rounded, their diameter varies between 15 and $30 \mathrm{~mm}$, and the color is green in summer and light red in autumn. The olive is composed of the pericarp (mesocarp or bark) and endocarp (pulp), which comprise the core. The pulp comprises 96 to $98 \%$ of the total oil value and the remainder is found in the seed (Methamem, Gouta, Mougou, Mansour \& Boujnah, 2015; Seçmeler \& Galanakis, 2019; Basumatary, Bhattacharya \& Das, 2020; Spika, Zanetic, Kraljic, Paskovic \& Skevin, 2018).

Olive fruit has well known and worldwide established nutritional benefits due to the presence of vitamins, minerals, bioactive compounds, high content of monounsaturated fatty acids and minor compounds, such as polyphenols and volatiles, 
responsible for the odor, bitterness and astringency in olive oils (Cheng, Zhan, Yang \& Zumstein, 2017; Rodrigues et al., 2020).

The fruit oil content increases during the ripening and its final amount, as well as the physicochemical characteristics of the fruit, vary according to the cultivation conditions, soil type, climate, rainfall, varieties and stage of maturation. During the extraction process, the yield of the lipid fraction will be entirely related to the moisture and dry matter concentrations (mainly by the oil content) and by the inherent characteristics of the processing (Cardoso et al., 2010; Spika et al., 2018).

Although the fruit directly influences the quality and composition of olive oil, the available information on ancient cultivars is considered scarce (Rodrigues et al., 2020). Table 1 presents the main characteristics of five olive cultivars recently introduced and cultivated in Brazil.

Arbequina is one of the most widespread cultivars in the world due to its easy adaptation to different cultivation systems and varying environmental conditions. The olive oil of this variety has a mild flavor and low astringency, which are sensory characteristics easily accepted by consumers. For these reasons, this cultivar is one of the most suitable for introduction into new markets. In Brazil, this variety is grown in the states of Rio Grande do Sul and Minas Gerais (Gonçalves, Rosa, Março \& Silva, 2020; Borges et al., 2017; Bruscatto et al, 2017).

Table 1: Characteristics of recent olive cultivars introduced in Brazil.

\begin{tabular}{ccccccc}
\hline Cultivar & Origin & Fruit weight & Fruit shape & Purpose & Phenolics value $^{\mathbf{1}}$ & Oleic acid value $^{\mathbf{2}}$ \\
\hline Arbequina & Spain & Low & Spherical & Oil & Low & Low \\
Ascolana & Italy & High & Ovoid & Table & Medium & High \\
Koroneiki & Greece & Low & Ovoid & Oil & High & High \\
Barnea & Israel & Medium & Elongated & Oil/Table & Medium & High \\
Grappolo & Italy & Medium & Spherical & Oil/Table & High & High \\
\hline
\end{tabular}

Source: IOC (2000), Vossen (2013). ${ }^{1}$ Phenolic compounds: low (less than 200 mg.kg-1); medium (200 - 400 mg.kg-1 $)$; high (400 - 600 mg.kg${ }^{1}$ ); very high (bigger than $\left.600 \mathrm{mg} \cdot \mathrm{kg}^{-1}\right)$; ${ }^{2}$ Oleic acid: low (less than $75 \%$ fat acids); medium (75- $80 \%$ fat acids); high (bigger than $80 \%$ fat acids) (Ilarioni \& Proietti, 2014).

The Koroneiki cultivar produces high-quality olive oil, with high oxidative stability, fruity flavor and herbaceous aroma. The Barnea cultivar is the result of genetic improvement, developed to increase the yield in oil extraction, presenting a medium fruity olive oil. The Ascolana variety has medium fruity oil, medium spicy and astringency and Grappolo has green fruity oil, with bitter notes and a striking flavor. In the state of Minas Gerais, the plantation in the city of Maria da Fé has a Brazilian variety, Grappolo 541, a clone of Italian Grappolo (Wiesman, 2009; Muzzalupo, 2012; Gonçalves et al., 2020).

The cultivars Arbequina, Ascolana, Koroneiki, Barnea and Grappolo 541 (Figure 1), were recently introduced in the city of Diamantina, Minas Gerais, with agronomic studies available in the literature (Martins, Cruz, Oliveira, Fagundes, \& Santos, 2015; Moreira, Fernandes, Cruz, Lima, \& Oliveira, 2016). 
Research, Society and Development, v. 10, n. 3, e32210313408, 2021

(CC BY 4.0) | ISSN 2525-3409 | DOI: http://dx.doi.org/10.33448/rsd-v10i3.13408

Figure 1: Olive cultivars recently introduced in the city of Diamantina, Minas Gerais (Brazil).
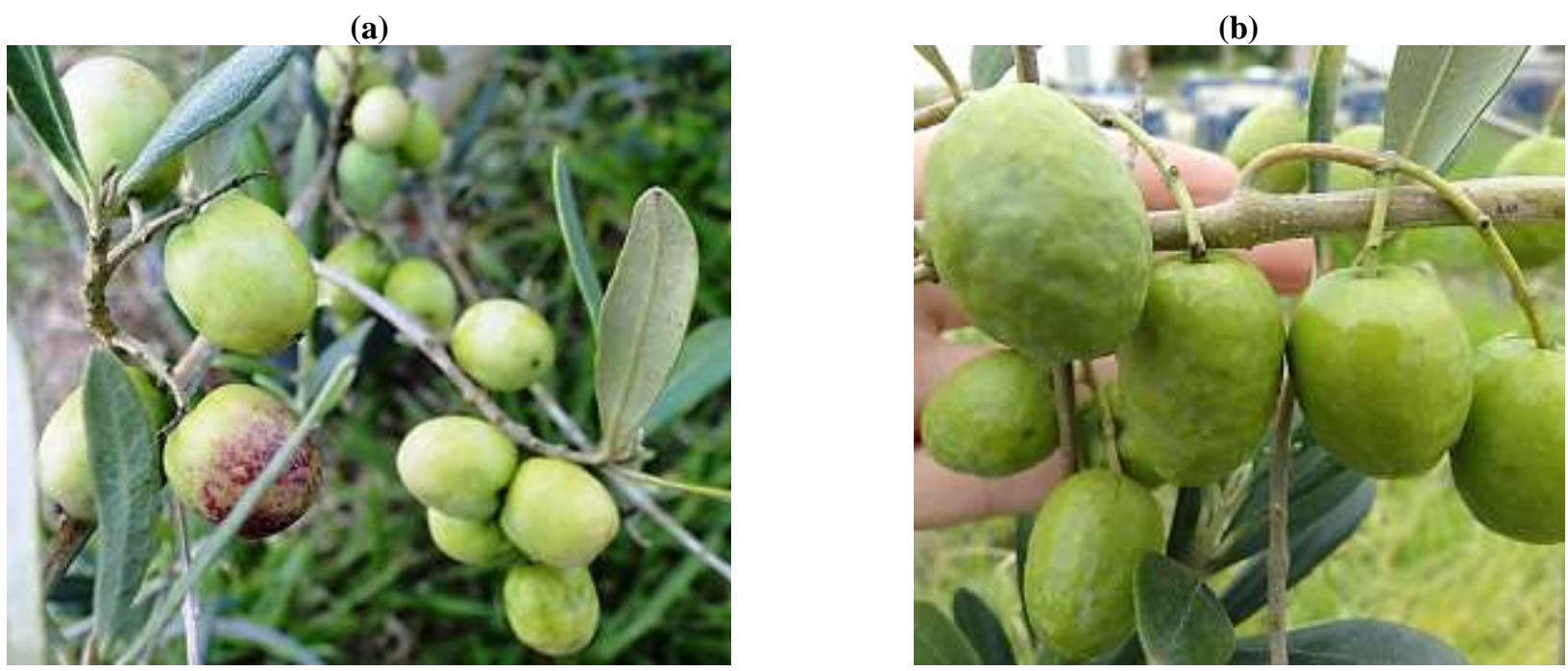

(c)

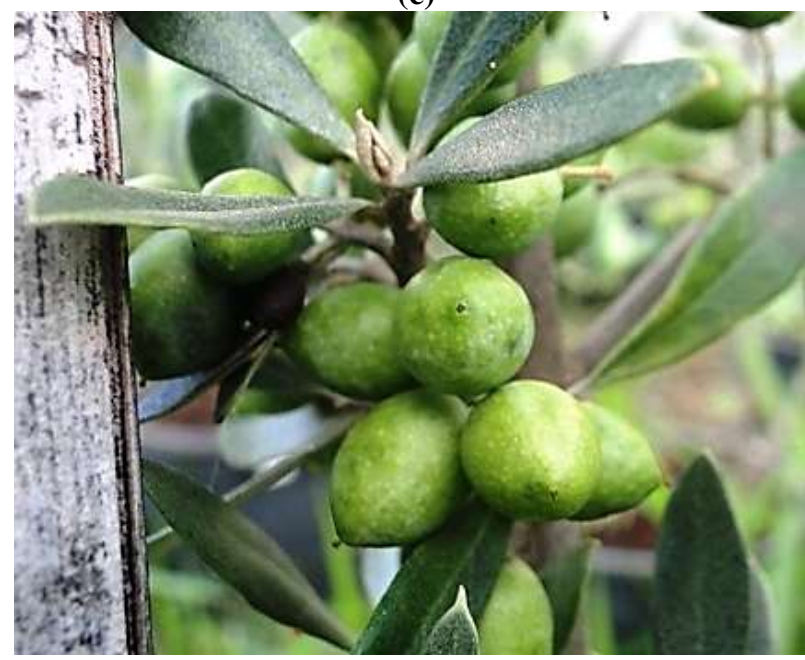

(d)

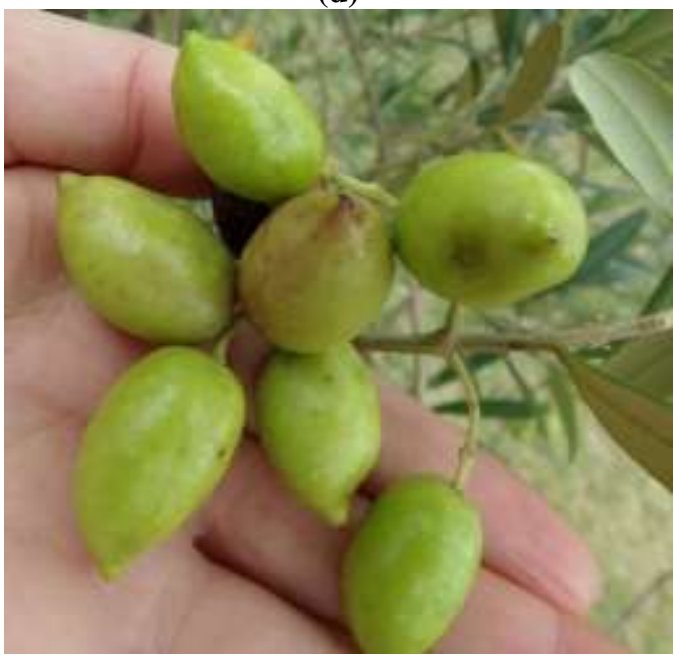

(e)

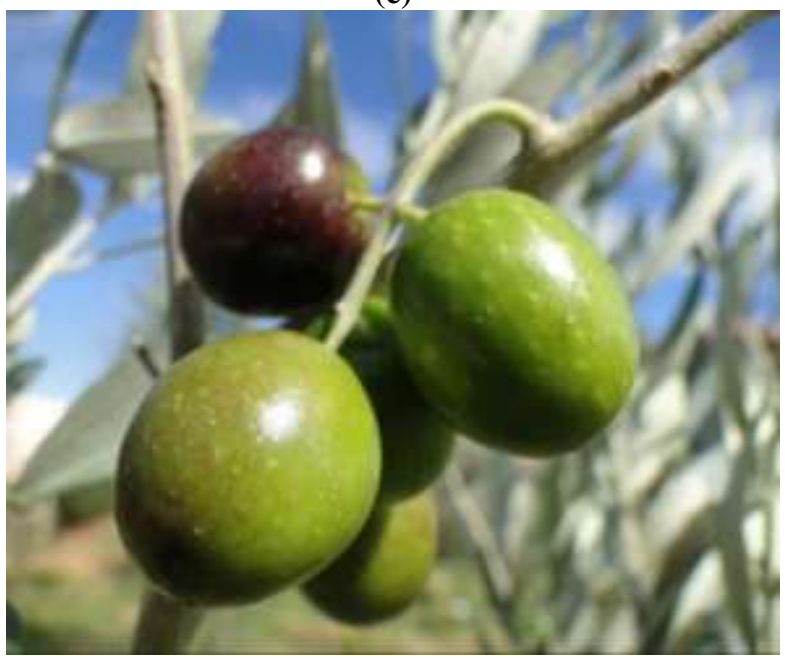

Source: Images provided by Prof ${ }^{a}$. Dr ${ }^{\text {a }}$. Maria do Céu Monteiro Cruz of the Faculty of Agricultural Sciences of the Federal University of Jequitinhonha and Mucuri Valleys (2018). (a) Arbequina, (b) Ascolana, (c) Koroneiki, (d) Barnea, (e) Grappolo 541. 


\subsection{Olive oil extraction}

The obtention process of a good quality olive oil, with high yield, starts at the harvest of the fruits, in its initial stage of maturation. By the traditional process, fruits are separated from the leaves, washed and processed using mills. The olive grinding and crushing produce the paste, which is subjected to the malaxation process. This stage is responsible for allowing the release of the initial lipid phase and subsequent agglutination of the oil droplets which will be separated by hydraulic presses: one binary phase is obtained, composed of water and oil. At the end of this process, the oil fraction is separated from the aqueous phase by centrifugation. The continuous separation process is used in several countries to replace the traditional method, is known as a two or three-phase system and has greater extraction capacity (Ciafardini \& Zullo, 2018; Rodrigues, Pimentel \& Oliveira, 2015).

The malaxation process is extremely important in olive oil extraction, especially if the procedure is carried out by the traditional method. The traditional method demands more time and allows the endogenous enzymes of the fruit (released in the crushing phase) to be in contact with the oil, triggering lipid oxidation reactions. Also, the longer the oil contact time with water released by the fruit, the greater the loss of phenolic compounds. For these reasons, it is not recommended that the mixing time be longer than 60 minutes and the temperature above $35^{\circ} \mathrm{C}$, which can cause loss of flavor and increase the astringency of the oil (Gharbi \& Hammami, 2019).

After extraction, numerous solid particles and microdroplets are present in the liquid residue of the solid paste, and the olive oil keeps an opaque appearance. During storage, physical and chemical characteristics are favored by the sedimentation and hydrolysis process of phenolic compounds (Ciafardini \& Zullo, 2018).

Two main residues are generated from olive oil extraction: the olive pomace, a semi-solid fraction composed of pulp, epicarp and crushed stone, and olive wastewater, a liquid effluent, which is the remaining liquid portion. These residues have the potential to be applied in new processes and to obtain new products with added value (Rodrigues et al., 2015; Medeiros, Villa, Silva \& Filho, 2016).

\subsection{Olive oil}

Olive oil is the oily part extracted from the fruit olives by cold processing, characterized as an aromatic liquid, yellowish-green and translucent. Larger-scale production takes place in countries in the Mediterranean region, such as Morocco, Spain, Greece, Italy, Turkey, among others, and annual world production varies from 2.6 to 3 million tons. Because olive trees have been cultivated for thousands of years in this region, the consumption of olive oil is highly widespread and has increased around the world due to its beneficial health properties and the highly appreciated sensory characteristics (Melo \& Pinheiro, 2012; Li et al., 2020; Ballus et al., 2014).

The sensory and chemical profile of olive oil is affected by the olive variety, climatic and cultivation conditions, degree of fruits ripeness, extraction method, refining process (when applied) and product storage condition, and these characteristics have a direct influence on its economic value (Uncu \& Ozen, 2020; Ballus et al., 2014).

Animal fat consists mainly of saturated fatty acids (SFA) and in vegetable oils, polyunsaturated fatty acids (PUFA) are predominant. However, olive oil differs from the others because it is rich in monounsaturated fatty acids (MUFA), as it occurs in high oleic sunflower, canola and peanut oils (Foscolou, Critselis \& Panagiotakos, 2018).

In addition to being edible, olive oil is rich in biological activity compounds, has a high MUFA content such as oleic acid (C18: 1, $\omega 9$ ), significant levels of essential fatty acids (linoleic acid - C18: $2 \omega 6$, acid $\gamma$-linolenic - C18: $3 \omega 6$ and $\alpha$ linolenic acid - C18: $3 \omega 3$ ), low levels in SFA and presence of minor components (volatiles, pigments such as chlorophyll and carotenoids, phenolic compounds, terpenes, hydrocarbons, sterols, tocopherols, phospholipids) that can reduce the incidence of chronic non-communicable diseases such as cardiovascular disease, brain cancer, colon cancer, metabolic syndromes, type 2 
diabetes and hypertension. Besides, due to the great importance of domestic use, the food industry is increasingly interested in the application of olive oil. Still, the non-food industry uses olive oil as a raw material in the manufacture of anti-aging cosmetics (Kalogianni, Georgiou \& Hasanov, 2019; Reboredo-Rodríguez, González-Barreiro, Cancho-Grande \& SimalGándara, 2014; Li et al., 2020).

The benefits that olive oil promotes to human health and the constant demand of consumers has made it famous worldwide and is currently produced in different parts of the world such as Africa, the United States and South America. Most of the olive oil consumed in Brazil is imported, which makes the product expensive and it's difficult to access by the majority of the population. Therefore, the expansion of olive culture in Brazil has a high potential for family farming and agribusiness growth. Countryside regions such as Rio Grande do Sul, São Paulo and south of Minas Gerais have already been starting to grow olive trees and extract oil (Silva, Oliveira, Pio \& Zambon, 2012; Ballus et al., 2014).

\subsection{Olive wastewater}

Olive wastewater is the liquid effluent from olive oil extraction and it is constituted by the fruit washing water, water contained in the fruit and the water added in the malaxation stage. The final composition of the wastewater contains a high content of phenolic compounds (between 0.5 and $24 \mathrm{~g} . \mathrm{L}^{-1}$ ), with the largest portion of hydroxytyrosol), soluble organic matter, nitrogen, phosphorus, potassium and magnesium (Rodrigues et al., 2015; Veneziani, Novelli, Esposto, Taticchi \& Servili, 2017).

The final chemical composition varies according to the olive oil extraction method used, and the residue has an acidic and toxic characteristic to the environment, and improper disposal is dangerous to terrestrial and aquatic ecosystems. Different methods of phenolic compounds extraction from olive wastewater are used to decrease toxicity and, at the same time, generate new value-added products for use in the cosmetic and food industry, such as membrane separation, liquid-liquid extraction and microwave-assisted extraction (Veneziani et al., 2017; Annab, Fiol, Vaillaescusa \& Essamri, 2019).

\subsection{Olive pomace}

Olive pomace is the semi-solid portion constituted by $30 \%$ cellulose, $39 \%$ pectic polysaccharides, $14 \%$ hemicellulosic polymers rich in xylans and glucoroxylans, $15 \%$ xyloglucans and $2 \%$ mannans and some minor components. The pomace chemical composition changes according to the variety of the fruit, cultivation conditions and extraction method. As its main characteristics stand out the low $\mathrm{pH}$, high concentration of organic matter and high salinity. In addition, it can improve physical and structural attributes such as texture, flavor, odor and oxidative stability in food and cosmetic products (Antónia-Nunes et al., 2018; Lama-Munoz, Rodríguez-Gutiérrez, Rubio-Senent \& Fernández-Bolaños, 2012; Rodrigues et al., 2015).

Olive pomace has a high content of dietary fibers, lipid composition rich in monounsaturated fatty acids and a high amount of phenolic compounds, which are known to help fight and inhibit the appearance of various types of diseases. The food enrichment with olive pomace allows the production of functional foods, with lower caloric value and lower saturated fat content. Besides, it was found that the use of phenolics in food can inhibit the growth of microorganisms, increase oxidative stability and prolong the shelf life of products (Medeiros et al., 2016, Veneziani et al., 2017).

The technological application of olive by-product requires that the drying of pomace before use to avoid the deterioration of the product by bacteria and fungi (mainly molds), and by reducing the amount of water to concentrations below $6 \%$. The use of olive pomace has been reported for application in edible oils, pasta, breads, cookies and snacks, hamburgers, fermented milk and smart packaging (Ahmad-Qasem, Barrajón-Catalán, Micol, Mulet \& García-Pérez, 2013; Difonzo, Troili, Squeo, Pasqualone \& Caponio, 2020). 


\subsection{Olive oil classification}

Olive oil is classified by quality criteria, considering the free acidity content and the extraction method (Figure 2). According to the Codex Alimentarius (IOC, 2003), olive oils are divided into the following types:

1 - Extra virgin olive oil: edible oil obtained from the fruit of the olive tree solely by mechanical processes or other physical means under conditions, particularly thermal conditions, which do not lead to the alterations in the oil, and which have not undergone any treatment other than washing, decantation, centrifugation and filtration, and whose acidity content does not exceed $0.8 \%$ (in oleic acid).

2 - Virgin olive oil: edible oil obtained from the fruit of the olive tree solely by mechanical processes or other physical means under conditions, particularly thermal conditions, which do not lead to the alterations in the oil, and which have not been undergone any treatment other than washing, decantation, centrifugation and filtration, and whose acidity content does not exceed $2.0 \%$ (in oleic acid).

3 - Ordinary virgin olive oil: virgin olive oil with a free acidity, expressed as oleic acid, greater than $2 \%$ and not more than $3.3 \%$. Ordinary virgin olive oil cannot be pre-packaged when destined directly to the final consumer, and must, necessarily, be destined for refining, and cannot be used to blend with refined olive oil.

4 - Refined olive oil: olive oil obtained from virgin olive oils by refining methods that do not change the initial glyceride structure, with a free acidity not exceeding $0.3 \%$ (in oleic acid).

5 - Olive oil: oil consisting of a blend of refined olive oil and virgin olive oil suitable for human consumption. It has a free acidity of not more than $1 \%$ (in oleic acid).

6 - Refined olive pomace oil: oil obtained from crude olive pomace oil by refining methods does not lead to alterations in the initial glyceridic structure. It has a free acidity, expressed in oleic acid, of not more than $0.3 \%$.

7 - Olive pomace oil: oil consisting of a blend of refined olive pomace oil and virgin olive oils. The acidity cannot exceed $1 \%$ (in oleic acid). 
Figure 2: Obtention ways and olive oil classification.

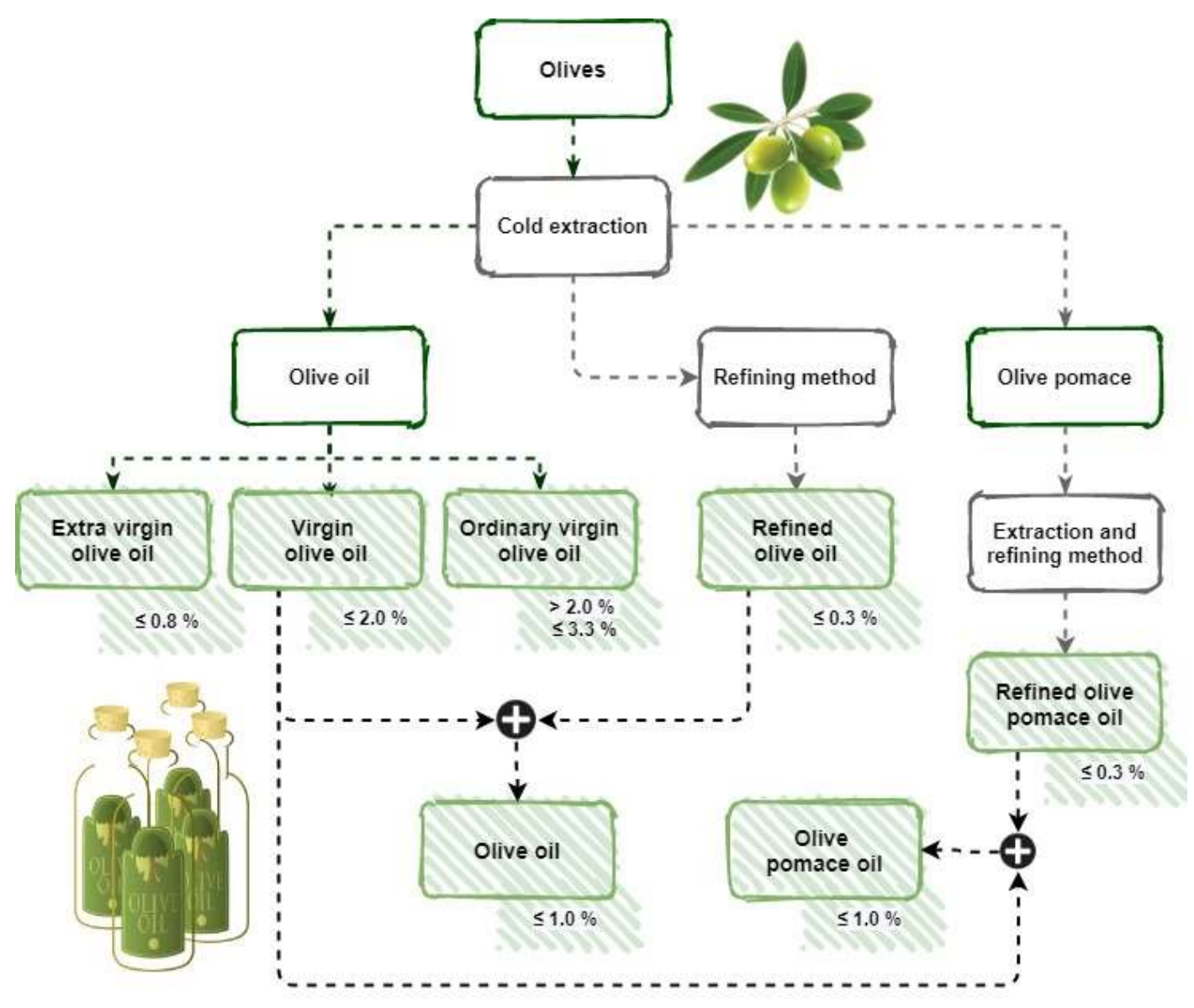

Source: Authors (2021).

\subsection{Oxidation reactions}

Fatty acids are the major components of olive oil, so, the most important chemical reactions are related to lipid content. The oxidation of lipids is an inevitable and irreversible process that happens due to the decomposition of the oil during processing and/or storage, but it can be minimized. Environmental factors contribute to the occurrence of these reactions, such as temperature, light and the presence of water and oxygen. Other factors such as the presence of free fatty acids, pigments, metalloprotein, oxidizing and pro-oxidizing enzymes decrease the stability of the oils, and the oxidation reactions are also dependent on the lipid structure: number and position of unsaturation (Silva, Borges \& Ferreira, 1999; Rotich, 2020).

The alteration in the quality of the lipids can occur by two main routes, which are called hydrolytic and oxidative rancidity. Hydrolytic rancidity has two mechanisms, which can be triggered by the presence of hydrolytic enzymes (lipases) or catalyzed by temperature in the presence of water (Ramalho \& Jorge, 2006).

Hydrolysis is a reversible reaction that converts glycerides into fatty acids and glycerol. Esterification is the reverse process, in which the carboxylic acid reacts with alcohol, forming ester and water (Figure 3). The hydrolysis of triacylglycerides occurs through the action of lipolytic enzymes present in the olive fruit in contact with the oil in the aqueous phase. The beginning of the reaction is due to the mechanical rupture of the fruits, in the grinding process, and this accelerates with the increase in temperature and/or time of contact with the released oil. When the oil is separated from the wastewater, lipolysis can slow down or cease completely. For this reason, the extraction carried out right after the harvest of healthy fruits results in olive oils with low values of free acidity (Mariotti \& Peri, 2014). 
Figure 3: Hydrolysis reaction and triacylglycerides esterification.<smiles>[R]C(=O)OC([R])C([R])=O</smiles>

Triacylglyceride

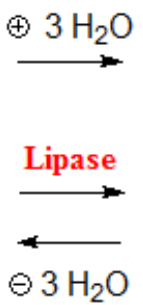

$\ominus 3 \mathrm{H}_{2} \mathrm{O}$<smiles>OCC(O)CO</smiles>

Glycerol<smiles>[R]C(=O)OC([R])=O</smiles>

Fatty acids

Source: Authors (2021).

Oxidative rancidity has three possible mechanisms: auto-oxidation, photo-oxidation and enzymatic oxidation. The latter not occurring in monounsaturated fatty acids, such as oleic acid (Damodaran \& Parkin, 2017).

Autoxidation (Figure 4) consists of a series of spontaneous reactions initiated by the addition of atmospheric oxygen to a fatty acid, proceeding until complete rancidification. The speed of these reactions is directly influenced by the number of unsaturation present in the carbon chain. Double bonds are the most reactive of the fatty acid molecules, mainly because they are in the unconjugated form. Thus, the presence of methylene carbons in the chain can double the rate of oxidation. Thus, polyunsaturated fatty acids (linoleic and linolenic) oxidize much faster than monounsaturated (oleic acid) (Araújo, 2019).

Figure 4: General mechanism of autoxidation.

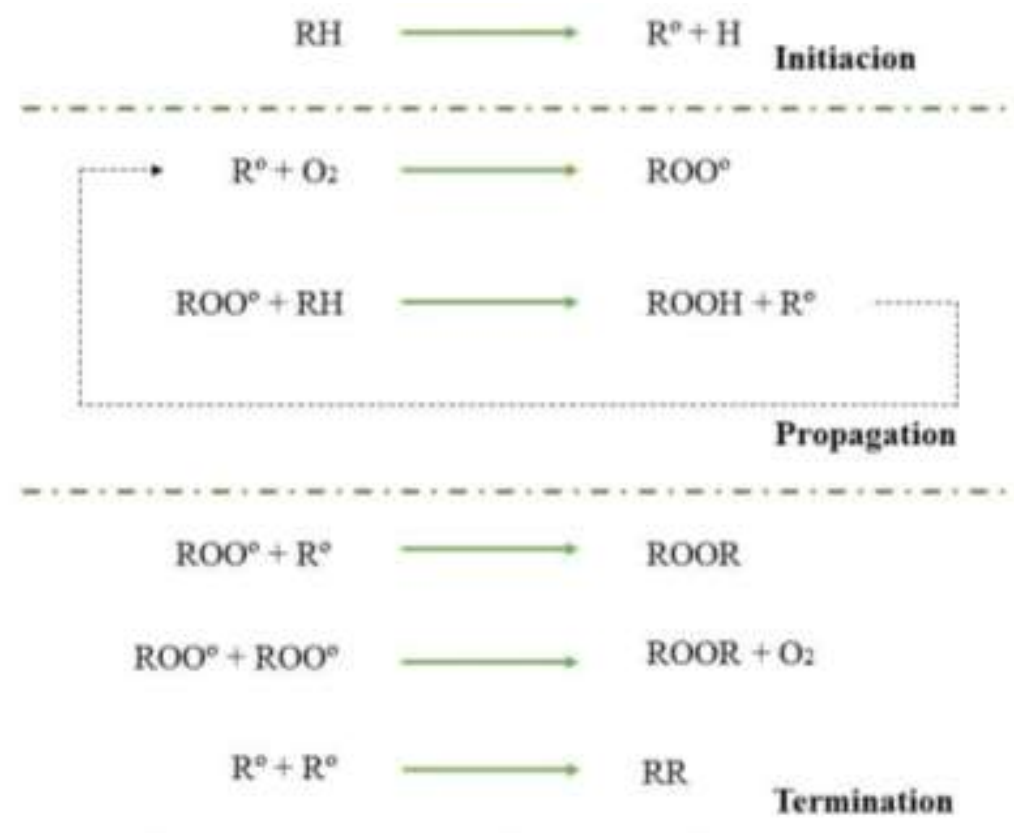

Source: Authors (2021). RH: unsaturated fatty acid; $\mathrm{R}^{\circ}$ : free radical; $\mathrm{ROO}^{\circ}$ : peroxide radical; $\mathrm{ROOH}$ : hydroperoxide.

The starting point of lipid autoxidation is the initiation step, where, due to the action of temperature, light or metals, a hydrogen atom separates from the fatty acid methylene carbon to form a free radical (Freire, Mancini-Filho \& Ferreira, 2013). 
During the propagation phase, occurs an addition of an oxygen atom to a free radical, originating the peroxide radical, and the first oxidation products are generated: peroxides and hydroperoxides. The hydroperoxide reaction formation is also responsible for the production of a new free radical by a hydrogen subtraction, restarting the process in a new fatty acid. Because these reactions occur with low enthalpy, the propagation phase is fast when compared to initiation (Freire et al., 2013).

Termination reactions are combinations between radicals to form the second oxidation products: stable, volatile and non-volatile molecules, responsible for off-flavor in food. In environments where there is a low concentration of oxygen, such as the frying process, free radicals can react with each other to form fatty acid dimers, increasing viscosity and resulting in oil browning (Freire et al., 2013).

Photo-oxidation is an alternative process that also leads to the formation of hydroperoxides, however, the initial reaction occurs by excitation of the photosensors present in the food (chlorophyll, riboflavin, myoglobin) or from oxygen by ultraviolet radiation. Oxidation of lipids can also occur through the action of lipoxygenase, an enzyme naturally present in vegetables, which catalyzes the reaction of adding oxygen to a polyunsaturated fatty acid chain. The action of the enzyme begins when the fruit suffers some type of physical damage during harvest, transport or mechanical processing. The substrates are linolenic and linoleic acids and the products generated are peroxides and hydroperoxides with conjugated double bonds, which will be involved in several new oxidation reactions (Mariotti \& Peri, 2014; Araújo, 2019).

\subsection{Olive oil quality and identity parameters}

The quality of extra virgin olive oil is defined by physical, chemical and sensory evaluations defined by Codex Alimentarius (IOC, 2003) and the parameters described in Table 2.

The free acidity in vegetable oils indicates the amount of free fatty acids present in the raw material or obtained during processing and storage, and it is determined through an acid-base reaction. Free fatty acids are formed by the occurrence of hydrolysis and enzymatic reactions, and the greater the presence of free fatty acids, the greater the negative effect on the quality of olive oil. The levels are highly variable in oils because they change according to the degree of ripeness and storage condition of the fruits used for oil extraction, the temperature and time of the extraction process and the storage conditions of the oil (Zicker et al., 2016; Osawa, Gonçalves \& Ragazzi, 2006).

The peroxide value is a parameter widely used in the analysis of oils and, although it is not strictly related to the degree of oxidation, it is an indicator of the initial damage caused by the decomposition of unsaturated fatty acids. When the peroxide concentration reaches a certain level, complex changes occur, forming low molecular weight compounds such as aldehydes, ketones, acids, alcohols and hydrocarbons, which are responsible for the taste and odor of rancid and sensorially unpleasant products (Wang, Ma, Yu \& Zhang, 2016; Araújo, 2019).

Despite being a simple titration method based on the conversion of potassium iodide into molecular iodine by the hydroperoxides present in the oil, the presence of light can influence the oxidation of iodine in excess by atmospheric oxygen, generating false results. In addition, the peroxides present in the oil can be transformed into secondary oxidation products, therefore, the index tends to decrease (Wang et al., 2016). 
Table 2: Parameters for olive oil evaluation.

\begin{tabular}{|c|c|c|c|c|c|c|c|}
\hline Parameters & $\begin{array}{c}\text { Extra virgin } \\
\text { olive oil }\end{array}$ & $\begin{array}{l}\text { Virgin } \\
\text { olive oil }\end{array}$ & $\begin{array}{c}\text { Ordinary } \\
\text { virgin olive } \\
\text { oil }\end{array}$ & $\begin{array}{l}\text { Refined } \\
\text { olive oil }\end{array}$ & $\begin{array}{c}\text { Olive } \\
\text { oil }\end{array}$ & $\begin{array}{c}\text { Refined } \\
\text { olive } \\
\text { pomace oil }\end{array}$ & $\begin{array}{c}\text { Olive } \\
\text { pomace oil }\end{array}$ \\
\hline $\begin{array}{l}\text { Free acidity } \\
(\% \text { oleic acid) }\end{array}$ & $\leq 0.8$ & $\leq 2.0$ & $\begin{array}{l}>2.0 \\
\leq 3.3\end{array}$ & $\leq 0.3$ & $\leq 1.0$ & $\leq 0.3$ & $\leq 1.0$ \\
\hline $\begin{array}{l}\text { Peroxide value } \\
\left(\text { meq. } \mathrm{O}_{2} \cdot \mathrm{kg}^{-1}\right)\end{array}$ & $\leq 20$ & $\leq 15$ & - & $\leq 5$ & $\leq 15$ & $\leq 5$ & $\leq 15$ \\
\hline Moisture (\%) & $\leq 0.2$ & $\leq 0.2$ & - & $\leq 0.1$ & $\leq 0.1$ & $\leq 0.1$ & $\leq 0.1$ \\
\hline $\begin{array}{l}\text { Relative density } \\
\qquad\left(\text { g.cm }^{-3}\right)\end{array}$ & $0.910-0.916$ & $0.910-0.916$ & $0.910-0.916$ & $0.910-0.916$ & $0.910-0.916$ & $0.910-0.916$ & $0.910-0.916$ \\
\hline $\begin{array}{l}\text { Saponification } \\
\text { value } \\
\left(\mathrm{mg} \mathrm{KOH.g} \mathrm{g}^{-1}\right)\end{array}$ & $184-196$ & $184-196$ & - & $184-196$ & $184-196$ & $182-193$ & $182-193$ \\
\hline $\begin{array}{l}\text { Unsaponifiable } \\
\text { matter }\left(\mathrm{g} \cdot \mathrm{kg}^{-1}\right)\end{array}$ & $\leq 15$ & $\leq 15$ & - & $\leq 15$ & $\leq 15$ & $\leq 30$ & $\leq 30$ \\
\hline $\mathrm{K}_{270 \mathrm{~nm}}$ & $\leq 0.22$ & $\leq 0.25$ & $\leq 0.30$ & $\leq 1.10$ & $\leq 0.90$ & $\leq 2.00$ & $\leq 1.70$ \\
\hline $\mathrm{K}_{232 \mathrm{~nm}}$ & $\leq 2.50$ & $\leq 2.60$ & - & - & - & - & - \\
\hline$\Delta \mathrm{K}$ & $\leq 0.01$ & $\leq 0.01$ & $\leq 0.01$ & $\leq 0.16$ & $\leq 0.15$ & $\leq 0.20$ & $\leq 0.18$ \\
\hline Color & $\begin{array}{c}\text { Light/yellow to } \\
\text { green }\end{array}$ & $\begin{array}{l}\text { Light/yellow } \\
\text { to green }\end{array}$ & - & $\begin{array}{l}\text { Light } \\
\text { yellow }\end{array}$ & $\begin{array}{l}\text { Light/yellow } \\
\text { to green }\end{array}$ & $\begin{array}{l}\text { Light/yellow } \\
\text { to brownish } \\
\text { yellow }\end{array}$ & $\begin{array}{l}\text { Light/yellow } \\
\text { to green }\end{array}$ \\
\hline $\mathrm{C} 14: 0$ & $0.0-0.05$ & $0.0-0.05$ & - & $0.0-0.05$ & $0.0-0.05$ & $0.0-0.05$ & $0.0-0.05$ \\
\hline C16:0 & $7.5-20.0$ & $7.5-20.0$ & - & $7.5-20.0$ & $7.5-20.0$ & $7.5-20.0$ & $7.5-20.0$ \\
\hline C16:1 & $0.3-3.5$ & $0.3-3.5$ & - & $0.3-3.5$ & $0.3-3.5$ & $0.3-3.5$ & $0.3-3.5$ \\
\hline $\mathrm{C} 17: 1$ & $0.0-0.3$ & $0.0-0.3$ & - & $0.0-0.3$ & $0.0-0.3$ & $0.0-0.3$ & $0.0-0.3$ \\
\hline C18:0 & $0.5-5.0$ & $0.5-5.0$ & - & $0.5-5.0$ & $0.5-5.0$ & $0.5-5.0$ & $0.5-5.0$ \\
\hline C18:1 & $55.0-83.0$ & $55.0-83.0$ & - & $55.0-83.0$ & $55.0-83.0$ & $55.0-83.0$ & $55.0-83.0$ \\
\hline C18:2 & $3.5-21.0$ & $3.5-21.0$ & - & $3.5-21.0$ & $3.5-21.0$ & $3.5-21.0$ & $3.5-21.0$ \\
\hline C18:3 & - & - & - & - & - & - & - \\
\hline C20:0 & $0.0-0.6$ & $0.0-0.6$ & - & $0.0-0.6$ & $0.0-0.6$ & $0.0-0.6$ & $0.0-0.6$ \\
\hline C20:1 & $0.0-0.4$ & $0.0-0.4$ & - & $0.0-0.4$ & $0.0-0.4$ & $0.0-0.4$ & $0.0-0.4$ \\
\hline $\mathrm{C} 22: 0$ & $0.0-0.2$ & $0.0-0.2$ & - & $0.0-0.2$ & $0.0-0.2$ & $0.0-0.3$ & $0.0-0.3$ \\
\hline $\mathrm{C} 24: 0$ & $0.0-0.2$ & $0.0-0.2$ & - & $0.0-0.2$ & $0.0-0.2$ & $0.0-0.2$ & $0.0-0.2$ \\
\hline
\end{tabular}

Source: IOC (2003).

When vegetable oil is subjected to a heating or frying process, the temperature directly influences the oxidation reaction causing the rate of peroxides formation to be less than the degradation. Thus, the peroxide index is not a good quality indicator of vegetable oils that have undergone heating, but it can be used for olive oil, since its predominant fatty acid is oleic, being less susceptible to oxidation reactions (Houshia et al.; 2019, Rios, Pereira \& Abreu, 2013). 
The specific extinction index (absorption in the ultraviolet at 232 and $270 \mathrm{~nm}$ ) is an important parameter for the evaluation of the quality of the olive oil. The increase in value in these regions may indicate the presence of substances from oxidative processes. The primary components of oxidation (dienes) are identified in the reading range between 220 and 234 $\mathrm{nm}$, and from $265 \mathrm{~nm}$ are identified trienes (secondary compounds such as aldehydes and ketones). The $\Delta \mathrm{K}$ method was proposed to characterize the oils concerning the adulteration of virgin and extra virgin oil with refined oil, reading at $270 \mathrm{~nm}$ only in conjugated triennia and subtracting the absorbance of chromophoric substances that absorb in the intensity between 260 $\mathrm{nm}$ and $280 \mathrm{~nm}$ (Huk et al., 2015; Houshia et al., 2019).

The TBARS index (substances reactive to thiobarbituric acid) is an alternative methodology for determining the degree of lipid oxidation. The method is spectrophotometric (reading at $532 \mathrm{~nm}$ ) and measures the amount of MDA (malonaldehyde), one of the secondary products of oxidation. Despite being an official methodology, the method is more used to detect peroxidation in animal fats (Papastergiadis, Mubiru, Langenhove \& Meulanaer, 2012).

The smoke point is an important physical parameter used to evaluate the stability of the oil on heating and is related to the accumulation of decomposition products. During the heating process, the appearance of smoke is indicative of the beginning of the process of nutritional degradation and the formation of compounds responsible for altering the flavor of the oil. Low smoke point values generally refer to low thermal stability (Khor et al., 2019).

Relative density is an important parameter for determining the molecular weight of fatty acids. The higher the content of unsaturated fatty acids, the lower the relative density of olive oil, provided by the lateral misalignment of fatty acids esterified in glycerol (Damodaran \& Parkin, 2017). The measure also allows verifying the adulteration of oils with oils of lower nutritional value or lower cost.

The unsaponifiable matter is also an indicator of oil adulteration. Unsaponifiables are the minority compounds present in olive oil, comprising the class of phenolic, organic and volatile compounds (Giacometti, Milin, Giacometti \& Ciganj, 2018). The saponification index is indicative of the amount of low and high molecular weight fatty acids present in olive oil (Almeida, Baggio, Mariutti \& Bragagnolo, 2015).

Phytosterols are compounds naturally found in plants that have biological activity and increase the vegetable oil's stability. They can be found in free form or esterified with fatty acids. One of its most important nutritional characteristics is the inhibition of the absorption of cholesterol. In olive oil, the most relevant phytosterols are campesterol, $\beta$-sitosterol and stigmasterol. Each edible oil has unique content of these compounds, therefore, the adulteration of olive oil by the addition of other cheaper vegetable oils or by processed oils is identified by the analysis of the phytosterols profile (Mansouri et al., 2019; Almeida et al., 2020, Lioupi, Nenadis \& Theodoridis, 2020).

The moisture content is a relevant quality olive oil parameter, as the existence of water is harmful, being the substrate for the occurrence of fatty acid hydrolysis. With the presence of free fatty acids, oxidation reactions are facilitated (Taluri, Jafari \& Bahrami, 2019).

Color is an important parameter in the olive oil presentation is closely related to the presence of chlorophyll $a$ and chlorophyll $b$, as well as in the form of pheophytin. Carotenoids are also present, mainly $\beta$-carotene, which helps to protect against the photo-oxidation phenomenon. The greenish color of the oils comes from chlorophyll and the intensity is an indication that the initial structure of the pigment was maintained, allowing us to infer that the oil did not undergo heating processes during the extraction (Scherer \& Böckel, 2018; Taluri et al., 2019).

The color changes in olive oils can probably be explained by the decomposition of chlorophyll in the process of exposure to light, by the relationship with the degree of fruit ripeness, fruit varieties or by heating during the centrifugation process (oil extraction phase) (Scherer \& Böckel, 2018). 


\subsection{Phenolic compounds}

Phenolic compounds are a class of substances that include various compounds, such as flavonoids, phenolic acids, phenolic alcohols and secairidoides. Despite having approximately thirty phenolic compounds, these are found in low concentration in olive oil, but expressive when compared to other vegetable oils. The main phenolics of olive oil are tyrosol, hydroxytyrosol and oleuropein (Figure 5), and the final content can be influenced by the fruit variety, method of oil extraction, cultivation and storage conditions. These compounds are powerful antioxidants and contribute to the sensory characteristics of olive oil such as bitterness and astringency (Huk et al., 2015; Houshia et al., 2019).

Figure 5: Main phenolic compounds found in olive oil.<smiles>OCCc1ccc(O)cc1</smiles><smiles>OCCc1ccc(O)c(O)c1</smiles>

Tyrosol

Hidroxityrosol<smiles>C=C(OC)C1=CO[C@H](O[C@@H]2O[C@H](O)[C@@H](O)[C@H](O)[C@H]2O)/C(=C\C)[C@@H]1CC(=O)OCCc1ccc(O)c(O)c1</smiles>

\section{Oleuropein}

Source: Authors (2021).

Oleuropein and its derivatives (tyrosol and hydroxytyrosol) are compounds found in less quantity in fruits and abundance in olive leaves, with antioxidant and anti-inflammatory effects and are responsible for the spicy flavor in olive oils. Oleuropein is part of the metabolism of fruits and, during ripening, levels decrease due to the conversion into glycosylated derivatives (Mariotti \& Peri, 2014; Cavaca, López-Coca, Silvero \& Afonso, 2020).

The concentration of oleuropein in olive oil is related to the degree of fruit ripeness and size. It is assumed that olive varieties with smaller dimensions may have higher phenolic content. During the grinding and malaxation processes of the olive oil extraction, the glycosidic portion of the oleuropein molecule is separated by enzymatic action from the endogenous $\beta$ glucosidase, producing non-glycidic compounds, the aglycones. Aglycone has a hydrophilic characteristic and only a small part remains in the final oil (Cavaca et al., 2020).

The minor components have been studied to be indicators of purity, quality and authenticity of the oil, in pure oils and blends. As in an olive oil refining process, phenolic compounds are removed, so in an adulterated olive oil, the quantification will be below the ideal value (Uncu \& Ozen, 2020; Houshia et al., 2019). 


\subsection{Health benefits of olive oil ingestion}

The presence of oleic acid, phenolic compounds and bioactive molecules in olive oil, especially in the extra-virgin type, makes it less susceptible to oxidation reactions. Thus, the consumption of olive oil can improve the lipid profile of the body, reducing the risk of chronic non-communicable diseases and, despite being a food with a high caloric value, it is not associated with an increase in body weight (Guasch-Ferré et al., 2020).

Several studies report the antioxidant and anti-inflammatory potential of olive oil. Guasch-Ferré et al. (2020) evaluated how olive oil consumption can decrease the risk of cardiovascular disease in adults in the United State; Gavahian et al. (2019) studied the impacts of olive oil on the intestinal microbiota and prevention of chronic diseases and found that the compound has an efficient action; Fernandes et al. (2020) investigated several scientific evidences that the regular consumption of olive oil provides an antiphlogistic response in the human organism; Román et al. (2019) concluded that extra virgin olive oil is promising in the prevention of Alzheimer's disease.

The Mediterranean diet and the frequent intake of olive oil contribute to reducing the risk of asthma in adults. Besides, it has been reported in the literature that the polyphenols present in olive oil were able to inhibit the growth of pathogens causing intestinal diseases and respiratory infections in studies conducted in vitro (Cazzoletti et al., 2019; Nazzaro et al., 2019). Protection against respiratory diseases has been one of the most important issues in the current scenario due to the pandemic caused by the new coronavirus.

COVID-19 is a new zoonosis caused by the SARS-Cov-2 virus, which originated in China in December 2019 and has spread around the world in subsequent months. It is an acute respiratory syndrome that affects people with mild, moderate or severe symptoms, causing death in the most severe cases. Due to its lethality, citizens from all parts of the world affected by the pandemic had to stay at home and restrict their habits and needs (Bracale \& Vaccaro, 2020, Bakalis et al., 2020).

The declaration of a global pandemic made by the WHO (World Health Organization) in January 2020 caused governments to decree quarantine, the closure of borders and the paralysis of tourism, measures that directly affected the first, second and third sectors of the economy, causing a world-wide economic crisis (Nicola et al., 2020).

When governments decreed confinement, there was a global phenomenon of compulsory shopping in supermarkets, probably due to the anxiety generated and the population thinking that they would be safe in the event of a global food shortage. There was a significant decrease in the consumption of fruits and vegetables and an increase in canned products, bread, milk, frozen foods and snacks (Bracale \& Vaccaro, 2020).

The change in human nutritional habits directly impacts health by inadequate intake of macro and micronutrients. As olive oil is rich in components that promote the inhibition, suppression and prevention of various types of diseases, the ingestion of these lipids could contribute to the increase of the immune resistance of the body, which maybe can increase the concentration of defense cells to alleviate symptoms caused by the pathogenic agent of COVID-19 (Bakalis et al., 2020, Foscolou et al., 2018). It is extremely important to highlight that this inference is not scientifically proven.

\section{Final Considerations}

The growth of olive trees and olive oil extraction has spread around the world due to the adaptation of olive trees in different environments and climates. Besides, the new markets seek the nutritional characteristics, beneficial health effects and unique sensory characteristics that are appreciated by consumers, and, consequently, the product offered becomes more accessible. The by-products from the olive oil extraction, mainly the olive pomace, have great potential for application in the food industry, in bakery products, for improving the flavor, aroma and texture, nutritional enrichment, antioxidant characteristic and prolonging shelf-life. 


\section{Acknowledgments}

The authors would like to thank the Federal University of Jequitinhonha and Mucuri Valleys (UFVJM) and the Institute of Science and Technology (ICT) for the institutional support. To the Coordination for the Improvement of Higher Education Personnel (CAPES) for granting the scholarship to B. S. Silva and financial support (funding code 001). We also are grateful to the National Council for Scientific and Technological Development (CNPq) for financial support (Universal project, protocol 424938/2016-2).

\section{References}

Ahmad-Qasem, M. H., Barrajón-Catalán, E., Micol, V., Mulet, A. \& García-Pérez, J. V. (2013). Influence of freezing and dehydration of olive leaves (var. Serrana) on extract composition and antioxidant potential. Food Research International, 50(1), 189-196. DOI: https://doi.org/10.1016/j.foodres.2012.10.028.

Almeida, D. S., Oliveira, D. F., Souza, A. S., Anjos, M. J. \& Lopes, R. T. (2015). Oil classification using x-ray scattering and principal component analysis. Anais do 2015 International Nuclear Atlantic Conference, São Paulo, Brasil.

Almeida, C. A. S., Baggio, S. R., Mariutti, L. R. B. \& Bragagnolo, N. (2020). One-step rapid extraction of phytosterols from vegetable oils. Food Research International, 130, 108891. DOI: https://doi.org/10.1016/j.foodres.2019.108891.

Annab, H., Fiol, N., Villaescusa, I. \& Essamri, A. (2019). A proposal for the sustainable treatment and valorization of olive mill wastes. Journal of Environmental Chemical Engineering, 7(1), e102803. DOI: https://doi.org/10.1016/j.jece.2018.11.047.

Antónia-Nunes, M., Costa, A. S. G., Bessada, S.; Santos, J.; Puga, H.; Alves, R. C.; Freitas, V. \& Oliveira, M. B. P. P. (2018). Olive pomace as a valuable source of bioactive compounds: a study regarding its lipid and water-soluble components. Science of the Total Environment, 644, 229-236. DOI: https://doi.org/10.1016/j.scitotenv.2018.06.350.

Araújo, J. M. A. (2019). Química de Alimentos: teoria e prática (7a ed.). Editora UFV.

Ballus, C. A., Meinhart, A. D., Campos Jr, F. A. de S., Silva, L. F. de O., Oliveira, A. F. de. \& Godoy, H. T. (2014). A quantitative study on the phenolic compound, tocopherol and fatty acid contents of monovarietal virgin olive oils produced in the southeast region of Brazil. Food Research International, 62, 74-83. DOI: https://doi.org/10.1016/j.foodres.2014.02.040.

Bakalis, S., Valdramidis, V. P., Argyropoulos, D., Ahrne, L., Chen, J., Cullen, P. J., Cummins, E., Datta, A. K., Emmanouilidis, C., Foster, T., Fryer, P. J., Gouseti, O., Hospido, A., Knoerzer, K., LeBail, A., Marangoni, A. G., Rao, P., Schüler, O. K., Taoukis, P., Xanthakis, E. \& Van Impe, J. F. M. (2020). Perspectives from CO+RE: how COVID-19 changed our food systems and food security paradigms. Current Research in Food Science, 3, 166-172. DOI: https://doi.org/10.1016/j.crfs.2020.05.003.

Basumatary, B., Bhattacharya, S. \& Das, A. B. (2020). Olive (Eleagnus latifolia) pulp and leather: characterization after thermal treatment ant interrelations among quality attributes. Journal of Food Engineering, 278, 109948. DOI: https://doi.org/10.1016/j.jfoodeng.2020.109948.

Borges, T. H., Pereira, J. A., Cabrera-Vique, C., Lara, L., Oliveira, A. F. \& Seiquer, I. (2017). Characterization of Arbequina virgin olive oils produced in different regions of Brazil and Spain: physicochemical properties, oxidative stability and fatty acid profile. Food Chemistry, 215, 545-462. DOI: https://doi.org/10.1016/j.foodchem.2016.07.162.

Bracale, R. \& Vaccaro, C. M. (2020). Changes in food choice following restrictive measures due to Covid-19. Nutrition, Metabolism and Cardiovascular Diseases, 30, 1423-1426. DOI: https://doi.org/10.1016/j.numecd.2020.05.027.

Bruscatto, M. H., Zambiazi, R. C., Crizel-Cardoso, M., Piatnicki, C. M. S., Mendonça, C. R. B., Dutra, F. L. G. \& Coutinho, E. F. (2017). Chemical characterization and oxidative stability of olive oils extracted from olive trees of Southern Brazil. Pesquisa Agropecuária Brasileira, 52(12), 1231-1240. DOI: https://doi.org/10.1590/s0100-204x2017001200012.

Cardoso, L. G. V., Barcelos, M. de F. P., Oliveira, F. de., Pereira, J. de A. R., Abreu, W. C. de., Pimentel, F. de A., Cardoso, M. das. \& Pereira, M. C. de A. (2010). Physicochemical characteristics and fatty acids profile of olive oils from different varieties of olive tree in southern Minas Gerais - Brazil. Semina: Ciências Agrárias, 31(1), 127-136. DOI: http://dx.doi.org/10.5433/1679-0359.2010v31n1p127.

Cavaca, L. A. S., López-Coca, I. M., Silvero, G. \& Afonso, C. A. M. (2020). The olive-tree leaves as a source of high-added value molecules: Oleuropein. Studies in Natural Products Chemistry, 64, 131-180. DOI: 10.1016/B978-0-12-817903-1.00005-X.

Cazzoletti, L., Zanolin, M. E., Spelta, F., Bono, R., Chamitava, L., Garcia-Larsen, V., Mattioli, V., Pirina, P. \& Ferrari, M. (2019). Dietary fats, olive oil and respiratory diseases in Italian adults: a population-based study. Clinical and Experimental Allergy, 49(6), 799-807. DOI: https://doi.org/10.1111/cea.13352.

Cheng, Z., Zhan, M., Yang, Z. \& Zumstein, K. (2017). The major qualitative characteristics of olive (Olea europaea L.) cultivated in southwest China. Frontiers in Plant Science, 8, 559. DOI: 10.3389/fpls.2017.00559.

Ciafardini, G. \& Zullo, B. A. (2018). Virgin olive oil yeasts: A review. Food Microbiology, 70, 245-253. DOI: 10.1016/j.fm.2017.10.010.

Damodaran, S. \& Parkin, K. L. (2017). Fennema's Food Chemistry (5a ed.). CRC Press.

Difonzo, G., Troili, M., Squeo, G., Pasqualone, A. \& Caponio, F. (2020). Functional compounds from olive pomace to obtain high-added value foods. Journal of the Science of Food and Agriculture, e10478. DOI: https://doi.org/10.1002/jsfa.10478. 
Ebiad, R. \& Abu-Quaoud, H. (2014). Morphological and biological characterization of three olive “Olea europaea L." cultivars in Palestine. Jordan Journal of Agricultural Sciences, 10(1), 130-143.

Fernandes, J., Fialho, M., Santos, R., Peixoto-Plácido, C., Madeira, T., Sousa-Santos, N., Virgolino, A., Santos, O. \& Carneiro, A. V. (2020). Is olive oil good for you? A systematic review and meta-analysis on anti-inflamatory benefits from regular diet intake. Nutrition, 69, 110559. DOI: 10.1016/j.nut.2019.110559.

Foscolou, A., Critselis, E. \& Panagiotakos, D. (2018). Olive oil consumption and human health: A narrative review. Maturitas, 118, 60-66. DOI: 10.1016/j.maturitas.2018.10.013.

Freire, P. C. M., Mancini-Filho, J. \& Ferreira, A. P. de. C. (2013). Major physical and chemical changes in oils and fats used for deep frying: regulation and effects on health. Revista de Nutrição, 26(3), 353-358. DOI: http://dx.doi.org/10.1590/S1415-52732013000300010.

Gharbi, I. \& Hammami, M. (2019). Olive (Olea europaea L.) Oil (Cap. 20, pp. 405-417). Switzerland: Springer Nature. DOI: 10.1007/978-3-030-12473-1_20.

Gavahian, M., Khaneghah, A. M., Lorenzo, J. M., Munekata, P. E. S., Garcia-Mantrana, I., Collado, M. C., Meléndez-Martínez, A. J. \& Baraba, F. J. (2019). Health benefits of olive oil and its components: impacts on gut microbiota antioxidant activities, and prevention of noncommunicable diseases. Trends in Food Science and Technology, 88, 220-227. DOI: https://doi.org/10.1016/j.tifs.2019.03.008.

Giacometti, J., Milin, C., Giacometti, F. \& Ciganj, Z. (2018). Characterization of monovarietal olive oils obtained from Croatian cvs. Drobnica and Buza during the ripening period. Foods, 7(11), e188. DOI: 10.3390/foods7110188.

Gonçalves, T. R., Rosa, L. N., Março, P. H. \& Silva, L. F. O. da. (2020). Evaluation of Brazilian monovarietal extra virgin olive oils using digital images and independent component analysis. Journal of the Brazilian Chemical Society, 31(9), 1955-1963. DOI: 10.21577/0103-5053.20200083.

Guasch-Ferré, L. G., Liu, G., Li, Y., Sampson, L., Manson, J. E., Salas-Salvadó, J., Martínez-González, M. A., Stampfer, M. J., Willett, W. C., Sun, Q. \& Hu, F. B. (2020). Olive oil consumption and cardiovascular risks in U.S adults. Journal of the American College of Cardiology, 75(15), 1729-1739. DOI: 10.1016/j.jacc.2020.02.036.

Houshia, O. J., AbuEid, M., Zais, O.; Shqair, H., Zaid, M., Nashariti, W., Noor, B. \& Al-Rimwai, F. (2019). Alteration of Nabali Baladi Extra Virgin Olive Oil (EVOO) chemical parameters as a function of air sunlight exposure. Oilseeds \& Fats Crops and Lipids, 26(38), 1-10. DOI: https://doi.org/10.1051/ocl/2019036.

Huk, T. T. S., Scapinello, J., Croce, D. M., Kihn, F., Bohn, A. \& Dal, M. J. (2015). Determinação da composição química e potencial antioxidante do azeite de oliva produzido na região oeste de Santa Catarina. Anais do XX Congresso Brasileiro de Engenharia Química, 1(2). DOI: 10.5151/chemeng-cobeq2014-105121350-172088.

Ilarioni, L. \& Proietti, P. (2014). Olive tree cultivars. (Cap. 5, pp. 59-67). Wiley. DOI: https://doi.org/10.1002/9781118460412.ch5.

IOC - International Olive Council. (2000). World Catalogue of Olive VarietiesIOC.

IOC - International Olive Council. (2003). Codex Standard for Olive Oils and Olive Pomace Oils - Codex Stan 33-1981 (2a rev.). Codex Alimentarius. Roma, Itália.

Kalogianni, E. P., Georgiou, D. \& Hasanov, J. H. (2019). Olive oil processing: current knowledge, literature gaps, and future perspectives. Journal of the American Oil Chemists' Society, 96(5), 481-507. DOI: https://doi.org/10.1002/aocs.12207.

Khor, Y. P., Sim, B. I., Abas, F., Lai, O. M., Wang, Y., Wang, Y. \& Tan, C. P. (2019). Quality profile determination of palm olein: potencial markers for the detection of recycled cooking oils. International Journal of Food Properties, 22(1), 1172-1182. DOI: https://doi.org/10.1080/10942912.2019.1634098.

Lama-Muñoz, A., Rodríguez-Gutiérrez, G., Rubio-Senent, F. \& Fernández-Bolaños, J. (2012). Production, characterization and isolation of neutral and pectic oligosaccharides with low molecular weights from olive by-products thermally treated. Food Hydrocolloids, 28(1), 92-104. DOI: https://doi.org/10.1016/j.foodhyd.2011.11.008.

Li, L., Deng, Y., Li, Z., Zhang, Z., Gao, X., Geng, X. \& Zhang, D. (2020). Resourcing potential of olive oil pomace. Thermal Science, 24(3A), 1761-1768. DOI: 10.2298/TSCI190603049L.

Lioupi, A., Nenadis, N. \& Theodoridis, G. (2020). Virgin olive oil metabolomics: A review. Journal of Chromatography, 1150, 122161. DOI: https://doi.org/10.1016/j.jchromb.2020.122161.

Mansouri, F., Moumen, A. B., Aazza, S., Belhaj, K., Fauconnier, M. L., Sindic, M., Caid, S. \& Elamrani, A. (2019). Quality and chemical profiles of virgin olive oils of three European cultivars suitable for super-high-density planting conditions in eastern Morocco. Materials Today: Proceedings, 13(3), 998-1007. DOI: https://doi.org/10.1016/j.matpr.2019.04.065.

Mariotti, M. \& Peri, C. (2014). The composition and nutritional properties of extra-virgin olive oil (Cap. 3, pp. 21-34). Wiley. DOI: https://doi.org/10.1002/9781118460412.ch3.

Martins, L. M., Cruz, M. do C., M., Oliveira, A. F., Fagundes, C. P. \& Santos, J. B. dos. (2015). Crescimento inicial de mudas de oliveira em competição com plantas daninhas. Revista Agrarian, 8(28), 124-132.

Medeiros, R. M. L., Villa, F., Silva, D. F. da. \& Filho, L. R. C. (2016). Destination and reuse of by products from olive oil extraction. Scientia Agraria Paranaensis, 15(2), 100-108. DOI: https://doi.org/10.18188/sap.v15i2.11905.

Mello, L. D. \& Pinheiro, M. F. (2012). Physico-chemical characterization of monovarietal olive oil and olive leaves of cultivars introduced in the RS State, Brazil. Alimentos e Nutrição, 23(4), 537-548. 
Methamem, S., Gouta, H., Mougou, A., Mansour, M. \& Boujnah, D. (2015). Yield, fruit oil content of some olive trees (Olea europaea L.) field-grown in Tunisia. Annals of Biological Research, 6(9), 64-71.

Moreira, R. A., Fernandes, D. R., Cruz, M. do C. M., Lima, J. E. \& Oliveira, A. F. de. (2016). Water restriction, girdling and paclobutrazol on flowering and production of olive cultivars. Scientia Horticulturae, 200(8), 197-204. DOI: https://doi.org/10.1016/j.scienta.2016.01.014.

Muzzalupo, I. (2012). Olive germplasm - Italian Catalogue of Olive Varieties. Croácia: InTech.

Nazzaro, F., Fratianni, F., Cozzolino, R., Martignetti, A., Malorni, L., De Feo, V., Cruz, A. G. \& d'Acierno, A. (2019). Antibacterial activity of three extra virgin olive oils of the Campania Region, Southern Italy, related to their polyphenol content and composition. Microorganisms, 7(9), 1-10. DOI: 10.3390/microorganisms7090321.

Nicola, M., Alsafi, Z., Sohrabi, C., Kerwan, A., Al-Jabir, A., Iosifidis, C., Agha, M. \& Agha, R. (2020). The socio-economic implications of the coronavirus pandemic (COVID-19): a review. International Journal of Surgery, 78, 185-193. DOI: 10.1016/j.ijsu.2020.04.018.

Osawa, C. C.; Gonçalves, L. G. \& Ragazzi, S. (2006). Potentiometric titration applied to free fatty acid determination of edible oils and fats. Química Nova, 29(3), 593-599. DOI: https://doi.org/10.1590/S0100-40422006000300031.

Papastergiadis, A., Mubiru, E., Langenhove, H. V. \& Meulenaer, B. de. (2012). Malondialdehyde measurement in oxidized foods: evaluation of the spectrophotometric thiobarbituric acid reactive substances (TBARS) test in various foods. Journal of Agricultural and Food Chemistry, 60(38), 9589-9594,

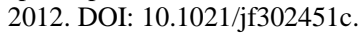

Ramalho, V. C. \& Jorge, N. (2006). Antioxidants used in oils, fats and fatty foods. Química Nova, 29(4), 755-760. DOI: https://doi.org/10.1590/S010040422006000400023

Reboredo-Rodríquez, P., González-Barreiro, C., Cancho-Grande, B. \& Simal-Gándara, J. (2014). Quality of extra virgin olive oils produced in an emerging olive growing area in north-western Spain. Food Chemistry, 164, 418-426. DOI: https://doi.org/10.1016/j.foodchem.2014.05.043.

Rios, H. C. S., Pereira, I. R. O. \& Abreu, E. S. (2013). Avaliação da oxidação de óleos gorduras e azeites comestíveis em processo de fritura. Revista Ciência e Saúde, 6(2), 118-126. DOI: https://doi.org/10.15448/1983-652X.2013.2.13143.

Rodrigues, F., Pimentel, F. B. \& Oliveira, M. B. P. P. (2015). Olive by-products: challenge application in cosmetic industry. Industrial crops and products, 70, 116-124. DOI: https://doi.org/10.1016/j.indcrop.2015.03.027.

Rodrigues, N., Casal, S., Peres, A. M.; Baptista, P. \& Pereira, A. A. (2020). Seeking for sensory differenciated olive oils? The urge to preserve old autochtonous olive cultivars. Food Research International, 128, 108759. DOI: https://doi.org/10.1016/j.foodres.2019.108759.

Román, G. C., Jackson, R. E., Reis, J., Román, A. N.; Toledo, J. B. \& Toledo, E. (2019). Extra-virgin olive oil for potential prevention of Alzheimer disease. Revue Neurologique, 175(10), 705-723. DOI: 10.1016/j.neurol.2019.07.017.

Rotich, V., Al Riza, D. F., Giametta, F., Suzuki, T., Ogawa, Y. \& Kondo, N. (2020). Thermal oxidation assessment of Italian extra virgin olive oil using an UltraViolet (UV) induced fluorescence imaging system. Spectrochimica Acta Part A: Molecular and Biomolecular Spectroscopy, 237, 118373. DOI: https://doi.org/10.1016/j.saa.2020.118373.

Scherer, R. \& Böckel, W. J. (2018). Avaliação dos teores de ácidos graxos presentes em azeites de oliva extra virgem comercializados no vale do Taquari. Revista Destaques Acadêmicos, 10(4), 246-259. DOI: http://dx.doi.org/10.22410/issn.2176-3070.v10i4a2018.2041.

Seçmeler, O. \& Galanakis, C. M. (2019). Olive fruit and olive oil (Cap. 8, pp. 193-220). Cambridge: Woodhead Publishing. DOI: https://doi.org/10.1016/B978-0-12-814887-7.00008-3.

Silva, F. A. M., Borges, M. F. M. \& Ferreira, M. A. (1999). Methods for the evaluation of the degree of lipid oxidation and the antioxidant activity. Química Nova, 1(22), 94-103. DOI: https://doi.org/10.1590/S0100-40421999000100016.

Silva, L. F. de O. da., Oliveira, A. F. de., Pio, R. \& Zambon, C. R. (2012). Agronomic and carpometric characterization of olive tree cultivars. Pesquisa Agropecuária Tropical, 42(3), 350-356. DOI: https://doi.org/10.1590/S1983-40632012000300012.

Spika, M. J., Zanetic, M., Kraljic, K., Paskovic, I. \& Skevin, D. (2018). Changes in olive fruit characteristics and oil accumulation in "Oblica” and "Leccino" during ripening. Acta Horticulturae, 1199(86), 543-548. DOI: 10.17660/ActaHortic.2018.1199.86.

Taluri, S. S., Jafari, S. M. \& Bahrami, A. (2019). Evaluation of changes in the quality of extraction oil from olive fruits stored under different temperatures and time intervals. Scientific Reports, 9, 19688. DOI: 10.1038/s41598-019-54088-z.

Uncu, O. \& Ozen, B. (2020). Importance of some minor compounds in olive oil authenticity and quality. Trends in Food Science and Technology, 100, 164176. DOI: https://doi.org/10.1016/j.tifs.2020.04.013.

Veneziani, G., Novelli, E., Esposto, S., Taticchi, A. \& Servili, M. (2017). Applications of recovered bioactive compounds in food products (Cap. 11, pp. 231253). Academic Press. DOI: https://doi.org/10.1016/B978-0-12-805314-0.00011-X.

Vossen, P. (2013). Growing olive for oil (Cap. 2, pp. 19-56). New York: Springer. DOI: 10.1007/978-1-4614-7777-8_2.

Zicker, M. C., Craig, A. P., Ramiro, D. de O., Franca, A. S., Labanca, R. A. \& Ferreira, A. V. M. (2016). Quantitative analysis of acidity level in virgin coconut oils by Fourier transform infrared spectroscopy and chemometrics. European Journal of Lipid Science and Technology, 118(9), 1350-1357. DOI: https://doi.org/10.1002/ejlt.201500407.

Wang, N., Ma, T., Yu, X., Xu, L. \& Zhang, R. (2016). Determination of peroxide values of edible oils by ultraviolet spectrometric method. Food Analytical Methods, 9(5), 1412-1417. DOI: http://dx.doi.org/10.1007/s12161-015-0322-4. 
Research, Society and Development, v. 10, n. 3, e32210313408, 2021

(CC BY 4.0) | ISSN 2525-3409 | DOI: http://dx.doi.org/10.33448/rsd-v10i3.13408

Wiesman, Z. Desert olive oil cultivation-Advanced Biotechnology. (2009). Academic Press. 